\title{
Ethnicity, Gender, Family, and Community in the Rural Midwest: A Review Essay
}

\section{SUZANNE SINKE}

Life at Four Corners: Religion, Gender, and Education in a German-Lutheran Community, 1868-1945, by Carol K. Coburn. Lawrence: University Press of Kansas, 1992. xii, 227 pp. Illustrations, maps, notes, bibliography, index. $\$ 29.95$ cloth.

Between Memory and Reality: Family and Community in Rural Wisconsin, 1870-1970, by Jane Marie Pederson. Madison: University of Wisconsin Press, 1992. xvi, 314 pp. Illustrations, maps, tables, notes, appendixes, bibliography, index. $\$ 50.00$ cloth, $\$ 17.95$ paper.

Prairie Patrimony: Family, Farming, and Community in the Midwest, by Sonya Salamon. Chapel Hill: University of North Carolina Press, 1992. xvii, 297 pp. Tables, appendix, bibliography, index. $\$ 45.00$ cloth.

ETHNICITY, gender, family, and community have all captured the interest of a growing number of scholars in recent years, the product of increased attention to everyday life and mentalite, as well as of a recognition of the diversity of the population in the United States. The three works under consideration here attempt to handle all of those issues concurrently - a formidable task. Despite differences in disciplinary approach, location, sources, and focus, they present striking commonalities about rural life in European-American enclaves - even on topics where they disagree.

THE ANNALS OF IOWA 53 (Fall 1994). OThe State Historical Society of Iowa, 1994. 
All three authors work to bring the study of the rural Midwest literally into the twentieth century and, in so doing, to challenge some of the existing models in their respective fields. For Coburn this means looking in depth at education in Block, Kansas, and redefining education to include what others generally term socialization. For Pederson it means a return to Merle Curti's Trempeleau County, Wisconsin, for another historical community study, this time stressing family and community continuity more than the democratizing and Americanizing elements of the frontier. For Salamon it means using a sociological field work project in northern Illinois to prove continuing ethnic differences among European-Americans, and thus to offer an alternative vision of agricultural development in the future.

The authors also share an explicit sense of personal connection to their subjects: Coburn's familial relation to many of the people included in her study, Pederson's rural Wisconsin upbringing, and Salamon's ethnic identification. The most important commonality, however, is that each of these studies stresses the significance of gender, ethnicity, family, and community in shaping rural life in the past. Only Salamon posits the same for the present and the future. All three describe similar developments; their disagreements arise out of their evaluation of those developments.

CAROL COBURN'S Life at Four Corners: Religion, Gender, and Education in a German-Lutheran Community, 1868-1945 offers much for historians, particularly historians of ethnicity and gender, to admire and much to critique. Coburn takes up the call of other historians of education (notably Lawrence Cremin) to examine institutions in addition to schools that are involved in the transmission of knowledge. In order to explore the ways a close, religiously and ethnically based community passes on its values, she studied Block, Kansas. German immigrants founded the community in the mid-nineteenth century and kept it in their own hands and those of their offspring for up to six generations.

In much of the book, Coburn focuses on the church and its related institutions, including parochial school, voluntary 
organizations, and social networks. For those familiar with Missouri Synod Lutheranism, there is nothing earthshaking in her revelations, but others may be surprised by the breadth of institutional control and social oversight in this world. Coburn treats this degree of control as almost unique, more akin to colonial New England than post-Civil War America. In fact, though, as the other two books under review here suggest, ethnicity and religion worked together among a variety of groups in many rural communities in this period to create multigenerational closed or semi-closed societies. ${ }^{1}$

Coburn organizes her discussion on the transmission of culture in Block around four "educational networks": church, school, family, and outside world (a catch-all for "other"). She works through a description of activities in each of these networks, relying primarily on church records and fifteen interviews she conducted in the 1980s. The church records are a tremendous source of information about much more than religious life. Unfortunately, Coburn uses her sources somewhat uncritically, and relies on translations of nearly all church documents. One of the hallmarks of ethnic continuity was the use of German in this community into the 1930s, even in the face of strong assimilationist pressure during World War I. The lack of skill in the original language is a handicap not only in the use of these documents but in denying the author and her readers access to what the highly literate people of Block read. The author had to rely on secondary sources for information about school curricula, youth publications, and local, regional, and international German-language papers and religious tracts.

Using oral interviews, on the other hand, offered Coburn insights into many aspects of life otherwise undocumented.

1. In addition to the works under consideration here, striking similar experiences appear in Rob Kroes, The Persistence of Ethnicity: Dutch Calvinist Pioneers in Amsterdam, Montana (Urbana and Chicago, 1992); and Royden K. Loewen, Family, Church, and Market: A Mennonite Community in the Old and the New Worlds, 1850-1930 (Urbana and Chicago, 1993). Even within the Lutheran church, other synods offer parallels in conservative values and ethnoreligious linkages, much more so than Coburn credits. In the Suomi Synod, for example, Finnish remained the primary language of church services up through 1945. See Carl Ross, The Finn Factor in American Labor, Culture, and Society (New York Mills, MN, 1978, 180-81. 
They are invaluable for her well-integrated focus on gender. For example, interviews form the basis of her discussion of how female domestics (or, as she calls them, hired girls) learned about new technologies and different roles through service in more urban areas early in this century. ${ }^{2}$ At several points, such as in her descriptions of affection and discipline within the family, these interviews add anthropological details. Readers can almost hear Coburn's grandmother regaling them with the stories of old. Yet the interviews suffer from a lack of clear chronology. The tremendous detail Coburn provides on the World War I years contrasts with the other chapters, where the dates skip from 1870 to 1930 and back without much notice. Coburn's statistics, based on church records, suffer from the same problem. Many of her figures are generalized to cover the years from 1885 to 1945, although she describes World War I as crucial in marking the deterioration of ethnic bonds and the shift from a closed community to more outside contact. Use of the U.S. manuscript census could have provided beneficial supporting evidence on this and many other points.

The process of Americanization ended, in Coburn's view, with World War II, so she ends her study there. She presents a picture, both literally (with engaging photographs) and figuratively, of four generations tied tightly into an ethnoreligious community, holding to traditional values of religion, family, and farm. By the end of the book, as a result of both internal and external pressures, this tightly knit group has largely disintegrated. The portrait is an engaging one and, for all of its flaws, an often informative one.

JANE MARIE PEDERSON'S community study, Between Memory and Reality: Family and Community in Rural Wisconsin, 1870-1970, parallels Coburn's work in many ways, although its scope is

2. Coburn's earlier article on this topic, "Learning to Serve: Educational Change in the Lives of Rural Domestics in the Twentieth Century," Journal of Social History 25 (1991), 109-22, challenged some views of EuropeanAmerican domestics in the twentieth century and (although she did not indicate it) reinforced several previous studies of Swedish, Finnish, Irish, German, and Dutch domestics. 
much broader and deeper. Pederson's laboratories of study are two rural townships in Trempeleau County, Wisconsin. Intentionally choosing the locale Merle Curti studied for his classic The Making of an American Community, she begins approximately where he ended. Her goal is to explore rural life beyond the frontier period, and to offer a chronology of change. Unlike Coburn, she is much more attuned to change as well as continuity, and she tries to document when and where change occurs. Although her scrutiny of religious matters is less thorough than Coburn's, her attention to demographics and family patterns beyond the memories of local inhabitants, as well as her sensitivity to variations found in a wider range of sources, make this a much more sophisticated study.

Pederson divides the history of the communities into three stages. The frontier or settlement phase, from 1850 to 1880 , she characterizes as a time of household production and local orientation. Because that was the period Curti studied, Pederson gives it somewhat less attention in the text. She does note, however, that the uniquely "American" mentalité Curti posited has resounding similarities to some of the newcomers' Norwegian origins. She also observes that the recent nature of EuropeanAmerican settlement meant a relative equality among those who came.

Pederson devotes most of her attention to the post-frontier years, from 1880 to 1945 . For that era she documents the development of relatively homogeneous rural communities. Nearly everyone left except the Norwegians, who took control of an increasing array of local institutions and developed a strong sense of community. "If the migrants from New York and New England were the driving force behind the 'making of an American community," "Pederson comments, drawing on Curti's theme, "the immigrant and ethnic cultures had much to do with the remaking of that community" (59). Economically, many farms made the shift from wheat to dairying, but continued their Norwegian patterns of communal work and cooperative organization of some tasks. Consumerism and technological innovations introduced changes into the community that were somewhat opposed to the high value placed on family and rural life. Pederson argues that many of the residents of 
these communities consciously chose a path of modest changes and limited growth as an alternative vision to urbanization and technological change. In this way, she manages to stress ethnic continuity while she remains attuned to changes in patterns of persistence.

In the final period, after 1945, according to Pederson, these rural communities were unable to maintain their autonomy. Outside intervention, whether from global markets or from the state board of education, combined with the interest of at least some of the residents in a different way of life to break down their resistance. Technology and opportunities for wage work (especially for women) also played a role. The number of farm families declined, although Pigeon Falls still retains-as a reminder of a schism in 1876-its two Lutheran churches, both descended from the Norwegian Synod. Like Coburn, Pederson basically ends her consideration of the communities with the Second World War, although officially (and in much of the quantitative analysis) she covers the period to 1970 .

Within this broader chronological framework, Pederson covers a variety of topics: familial persistence, marriage and intermarriage, voting and political culture, farm and other business patterns and ideologies, migration, religion, gender roles, sociability, and changing ideas of morality. Pederson relies on a substantial body of demographic sources, which she summarizes in numerous tables. Photographs and interviews are more peripheral in this text, although they add substantially to the human element in the story. The anthropological detail Pederson draws from historical collections provides information on rural life, and she uses innovative techniques to draw out some information, such as the visitation patterns she discerned from the ubiquitous comments in the local newspaper about who was in town.

As late as 1970, 40 percent of county residents reported something other than English as their mother tongue, and most people in her study still attended Norwegian church services. Well into the twentieth century - up until World War II in many cases - even outsiders learned Norwegian in order to trade in the area. Yet Pederson, like Coburn, lacked the knowledge of the languages of her subjects. To make up for this 
glaring inadequacy, Pederson relies heavily on other studies of the upper Middle West by authors with Norwegian language skills who did similar community studies. She could not turn to other scholars for background on the small Polish rural contingent in her study area, for they are virtually absent from the historical literature.

Pederson's tone is characterized by an admiration for smalltown solidarity and community. Occasionally, in her effort to overturn negative stereotypes of rural life, Pederson errs in the other direction, romanticizing the golden age of agriculture. Yet with her clear prose and solid supporting data, she offers a close look at rural patterns into the recent past, and illustrates once again the importance of religion and ethnicity in addition to family choices in creating a sense of community that survived against substantial odds.

SONYA SALAMON'S Prairie Patrimony: Family, Farming, and Community in the Midwest reflects one of Pederson's points: when sociologists have looked at rural places, they have not always seen the same patterns as historians. By far the most ambitious and nuanced of the works under consideration here, this monograph is the result of approximately ten years of field work by Salamon and her graduate students in family studies at the University of Illinois. Many of the results of this project have already appeared in articles, but this book represents the academic culmination of the project. Salamon, taking an anthropological approach, begins with the present and works backward through time to see how the patterns that were clear to her in the 1980s emerged. Unlike the other two authors, Salamon does not see ethnicity lost in the realm of the past. Rather, it is a continuing phenomenon in the areas she studied, and it may, she strongly suggests, hold the best hope for future developments in rural life.

Salamon compares seven towns in northern Illinois, each of which she and sometimes one of her students studied for at least a year. She breaks the towns into three categories based on the ethnic roots of the current residents: "German," "Yankee" (Salamon's term for persons of British descent), and mixed. 
The design is exceedingly methodical, so that "German" here includes three towns each with a different German regional and religious background (East Frisian, Alsatian, and Westphalian). These and the three "Yankee" towns also had varying proximities to regional urban centers and transportation links. The author even uses communities occupying two different soil regions for each group, thus finding information on communities growing different crops with different degrees of success. Thus, the author tried to control for possible intervening factors. Within this framework, she focuses on land. As she notes, "How land is handled reflects what farm families want for themselves and value about the future or the past" (4).

Salamon's conclusions are clear. There are two cultural patterns at work. The German yeoman pattern emphasizes continuity of land within the family, placing as many of the children as possible in the area. They follow conservative fiscal policies that will not endanger these goals, and form cooperative family farming units that may favor one sibling over another, but generally contribute to family solidarity. The results of this yeoman pattern for the communities involved are relatively stable populations, somewhat smaller average farm size, relatively little economic variation within the group, and active rural communities that can withstand various crises. The Yankee counterpart Salamon labels the entrepreneurial pattern, in which farming is viewed as a business that may or may not stay in the family. Technology and risk play much larger roles in farm management; and cooperation, even within the family, is less common. For the community, these kinds of activities result in more mobile populations, with larger economic differences among them, more clustering at the extremes of tenants and agribusiness, and less commitment to the rural community by its residents. The two models are complementary, for they act in opposite ways during economic cycles. Thus the entrepreneur, either because of possible profits, or more likely riskinduced losses, often sells out over time to the yeoman, who has assiduously saved (no vacations to Florida here) in order to do exactly that. In this way, those of German ancestry have managed to maintain and add to their holdings in rural areas. 
Entrepreneurs, on the other hand, introduce innovations and operate on a scale that allows greater use of technology. Salamon keeps her comments on the positive and negative aspects of each ideal in balance for most of the book, only to indicate in the conclusion that the yeoman pattern offers a better model for sustainable development in the future.

In order to come to these conclusions, Salamon and her students interviewed hundreds of individuals and families in these communities, spent time in participant observation of their daily tasks, and worked through land records, church documents, and other local sources to verify what they heard. In keeping with anthropological conventions, the people are anonymous, and the quotes are "reconstructed" from memories recorded in field notes. The sentiments and the patterns she describes resound with the voices of Block, Kansas, and Trempeleau County, Wisconsin. In both of the other books, the authors discuss the importance of family farming and the continuing ethnoreligious community. Both also note how the German or Norwegian traditions of women's roles on the farm contrast with those of neighbors of British ancestry. But whereas the other two books point to an increase in out-migration since World War II, Salamon shows this migration to be much less a factor among yeoman families than among entrepreneurial ones. Is there actually a difference? The women Pederson discusses who engaged in paid work in a nearby urban area in the 1970 s replicate the pattern Salamon posits for yeoman in areas near urban centers. Likewise, Coburn discusses how fifth- and sixth-generation farmers in Block are still holding on, against all odds, and how people still value the church and their heritage. Salamon says the "disappearing family farms" are not actually disappearing to the extent many think, and those that are tend to be entrepreneurial ones. Culture, in her view, continues to be of paramount importance in the treatment of the land over generations and, by implication, in the treatment of other things as well.

Salamon may overstate the continuity of these yeoman communities at some points, but the correspondence of her model to patterns found in other studies is too striking to 
disregard. ${ }^{3}$ Salamon, to a much greater degree than Coburn or Pederson, assumes that a culture will change over time. Thus a shift in language or a smaller percentage of persons in one economic category does not necessarily mean that ethnicity no longer exists. Salamon's more controversial argument is that a "Yankee" ethnicity continues among those who would adamantly deny it. This is not exactly a rehashing of David Hackett Fischer's version of the "germ theory" in Albion's Seed, but neither does Salamon credit much to the surrounding environment.

THESE THREE BOOKS have important implications for the study of the rural Midwest. Yet for the study of ethnicity, a continuum with more closed group-oriented subcultures or communities at one end and more open individual-oriented ones at the other end might offer a better model than either the ideal patterns or dichotomous variables presented in these books. A continuum could allow for more variation within a group. Such a continuum already appears in much of the internecine bickering within ethnoreligious groups, where some want to adopt new patterns and others resist, where religious schisms and individual decampments result from differing opinions. We can go beyond "cultural islands."

In addition, to take issues of ethnicity into the fifth generation and beyond, as these authors do, requires a recognition of shifts in cultural patterns. Definitions of group identity built on language retention alone are no more promising than those based on physical features. Discrimination, either in legal or social form, plays a much larger role for non-European groups

3. Kathleen Neils Conzen, for example, has been engaged in a study of Stearns County, Minnesota, for a number of years. For her view on the "German" pattern of land ownership, see her "Peasant Pioneers: Generational Succession among German Farmers in Frontier Minnesota," in Steven Hahn and Jonathan Prude, eds., The Countryside in the Age of Capitalist Transformation: Essays in the Social History of Rural America (Chapel Hill, NC, 1985), 259-91.

4. Walter M. Kollmorgen used this term in "Immigrant Settlements in Southern Agriculture: A Commentary on the Significance of Cultural Islands in Agricultural History," Agricultural History 19 (1945), 69-77. His use of the phrase indicates that the idea of "unique" ethnic enclaves goes well beyond the Midwest. 
than for the groups included in these studies, but it is a potent force affecting group behavior in any setting, as the comments on English-only legislation and the fire-bombings of GermanAmerican churches during World War I attest. Two of these studies point to World War II as pivotal in breaking down the last vestiges of rural isolation and ethnic homogeneity. That proposal deserves more serious study than these authors provide.

These studies also contribute to a growing understanding of gender in the rural Midwest, particularly in the twentieth century. All three consider gender in terms of both men and women at different life stages. In this, they demonstrate variations among European-American groups. All three tacitly or openly posit that family farming operates by subordinating the interests of certain individuals to the good of the family; within a patriarchal system that means men consistently hold the greatest power. All three note specific forms of patriarchy, but they evaluate differently how women interpreted their situation. None are as pessimistic as Deborah Fink has been in her studies of rural midwestern women. ${ }^{5}$ Salamon openly challenges Fink's view, stating that women involved in the yeoman system have extensive social and kinship networks that mitigate exactly the kind of isolation and abuse Fink associates with rural life. Pederson affirms the ability of her rural community, at least in the past, to uphold its values, including limiting abuse of women. ${ }^{6}$ All three indicate that unless women are willing to continue a system in which they have not held equal power with men, rural family farming will change significantly, and perhaps even disappear.

Will ethnicity, family farms, and rural communities endure in the Midwest? The authors cannot offer definitive answers.

5. Deborah Fink, Open Country, Iowa: Rural Women, Tradition and Change (Albany, NY, 1986); idem, Agrarian Women: Wives and Mothers in Rural Nebraska, 1880-1940 (Chapel Hill, NC, 1992).

6. Pederson makes this point even more clearly in "Gender, Justice, and a Wisconsin Lynching, 1889-1890," Agricultural History 67 (1993), 65-82. Coburn is somewhat less certain, indicating that abuse may still occur. My own research on church disciplinary cases concerning familial abuse showed little evidence of communal support for abused wives. See "Give Us This Day: Dutch Immigrant Women in Two Protestant Denominations, 1880-1920," Amerikastudien 38 (1993), 425-39. 
They can and do point to the historical record of persistence, and to the value of roots in the soil. Salamon, by making more specific comparisons with the present, offers a better explanation for why some communities survive while others disintegrate. That the other two books tend, in many ways, to support her findings points to the benefits of more direct comparative work. For individual scholars, learning the languages and worldviews of several different groups poses an almost insurmountable barrier. But doing community studies without that knowledge may seriously affect the results. Rather, we may seek out cooperative projects, with explicit comparisons built into the design. Failing that, we can design our projects with others in mind, and make our categories and comparisons (as Pederson does in relation to Curti's) clear. Our communities, then, will undoubtedly appear less "unique." 
Copyright of Annals of Iowa is the property of State of Iowa, by \& through the State Historical Society of Iowa and its content may not be copied or emailed to multiple sites or posted to a listserv without the copyright holder's express written permission. However, users may print, download, or email articles for individual use. 